\author{
Paulina Zajadeo-Węglarz
}

\title{
The Up-to-Dateness of the Debate on Responsibility to Protect
}

\section{Towards Sovereignty as Responsibility}

No doubt we have been observing in recent years the phenomena inclining us towards reflection about the possible axiological and normative transformation of the international law paradigm ${ }^{1}$. In general, we observe an attempt to constitutionalize international law that evolves from a primitive set of first-order rules to a broadly understood system with a complex internal structure. Some authors even talk about the rise of Global Law ${ }^{2}$ built over traditional international law. Others call it Humanity's Law $w^{3}$. It must be admitted that constitutionalization is nowadays a very attractive concept, albeit still "the unsolved riddle" 4 . The doctrine also indicates a tendency to the opposite process, i.e. international law fragmentation caused by the increasing differentiation of individual spheres of international cooperation ${ }^{5}$. Autonomous normative systems that regulate individual spheres of international relations are created - they include both substantive and procedural rules. Contemporary international law is no longer limited only to resolving interstate conflicts, but has become a versatile instrument to regulate broadly understood international relations. International law that until recently operated mainly in the area

1 J. Zajadło, Aksjologia Prawa Międzynarodowego a filozofia prawa (uwagi na marginesie doktryny Responsibility to Protect), [in]: Aksjologia wspótczesnego prawa międzynarodowego, ed. Wnukiewicz-Kozłowska A., Wydawnictwo Uniwersytetu Wrocławskiego, Wrocław 2011, p. 307 et seq.

2 J. Zajadło, Konstytucjonalizacja prawa międzynarodowego, in: Leksykon prawa międzynarodowego publicznego. 100 podstawowych pojęć, eds. A. Przyborowska Klimczak, D. Pyć, C. H. Beck, Warszawa 2012, pp. 131-138; cf. among others R. Domingo, The New Global Law, Cambridge University Press, New York 2011

3 R. G. Teitel, Humanity's Law, Oxford University Press, Oxford-New York 2011.

4 I. de la Rasilla del Moral, The Unsolved Riddle of International Constitutionalism, International Community Law Review, 2010, vol. 12, no 1, pp. 81-110.

5 A. Wiśniewski, Fragmentacja prawa międzynarodowego, in: Leksykon prawa międzynarodowego publicznego..., op. cit., pp. 65-68 
of law dogmas must, if it wants to be effective, also open up to other areas of knowledge: ethics, the philosophy of law, political philosophy, theory of international relations etc. ${ }^{6}$ Revaluation of the sovereignty rule is certainly the most frequently contested attempt to revise the fundamental categories of international law. It seems that joint actions undertaken by international communities to solve problems concerning risks to peace or security or infringements of human rights occur against the legal nature of sovereignty that forms an integral part of the fundamental rules of international law. The number of advocates of a new theory of state sovereignty in international relations is nearly the same as the number of those who oppose all changes. However, it must be strongly emphasized that the responsibility to protect principle does not endanger state autonomy; just the opposite - as Kofi Annan, the Secretary-General of the United Nations claimed, it rather supports and strengthens state autonomy. Despite multi-faceted links between the international community and the ongoing development of international law, the sovereignty principle still remains the core category of international relations. We observe, however, progress in the process of changes and R2P is one of its hallmarks. The role of the state is not based solely on supreme authority and absolute self-governance (to refer to Cezary Berezowski's rhetoric), but it also generates responsibility. Moreover, the doctrine more and more openly tends to empower the individual, although it provides an individual only with selected elements of the capability to participate in international relations. Some are even of the opinion that an international community as a whole should be deemed a holder of rights ${ }^{8}$.

\section{From an Idea to the Official Doctrine}

The Responsibility to Protect concept was created as the result of an initiative of a group of intellectuals. Initially it was a reaction to problems resulting from the clash between fundamental principles of international law, such as the equality of sovereignty between nations, non-interference in their internal affairs, the use of force in inter-state relations, and the need to protect and comply with human rights. A problematic intervention in Kosovo was the pretext for attempts to re-interpret former positions concerning the prohibition on both formulating threats and the use of force in inter-state relations. In its definition of the term responsibility to protect, the ICISS report made reference - terminologically - to the sovereignty as responsibility concept formulated by Francis M. Deng

6 J. Zajadło, Aksjologia prawa międzynarodowego..., p. 8.

7 A. Peters, Humanity as $A$ and $\Omega$ [Omega] of Sovereignty, European Journal of International Law, 2009, vol. 20, no 3, pp. 513-544.

8 A. A. C. Trynidade, International Law for Humankind, Brill, Boston-Leiden 2010, pp. 275-288; in particular chapter XI Humankind as a Subject of International Law. 
(the then Representative of Internally Displaced, later the Secretary-General's Special Advisor on the Prevention of Genocide), and - conceptually - to the humanitarian intervention concept, which makes use of the premises derived from the just war theory. The report authors postulated a re-conceptualization of the whole debate on the use of force and humanitarian intervention and, in order to change the perspective, proposed a new formula of responsibility: responsibility to prevent, responsibility to react and responsibility to rebuild. The unfortunate timing of the end of the work on the report - a few days before the terrorist attacks on the USA of September 11th - justified the concern that $\mathrm{R} 2 \mathrm{P}$ would die a natural death. When the whole world was engaged in the war with terrorism and the war in Afghanistan it was difficult to popularize such an innovative idea. Some even predicted the end of humanitarian intervention ${ }^{9}$. However, the concept that initially seemed to be only an idea proposed by a group of scholars, soon transformed into one of the most dynamically developing theories of modern international relations. If we compare the effectiveness of theCommissions established to solve contemporary global problems, only the World Commission on Environment and Development headed by Gro Harlem Brundtland achieved a success similar to that of ICISS in implementing its concepts: "The role that international or independent commissions have played in linking ideas and institutions has not received the attention it merits. The names of many of the key commissions, often best remembered by the individuals who headed them - Brandt, Palme, Brundtland, Carlsson/Ramphal, for example - continue to be recognized. But the impact of commissions - what they have achieved, and how they have done it,both individually and collectively - has been too often neglected" ${ }^{10}$. The analysis of the growth dynamics shows the international community's quickly progressing acceptance of the new idea. The enthusiasm for the concept was seen for the first time at the 2005 World Summit (i.e. four years after the idea's formulation) - R2P was included in the Summit Outcome Document. It must be noted that the concept ceased to be the topic for the solely theoretical considerations of a group of experts, as it was used to express the position of the United Nations member states - even if only in the form of non-binding arrangements. Some even recommended including the responsibility to protect principle in the official UN doctrine ${ }^{11}$.

9 T. G. Weiss, The Sunset of Humanitarian Intervention? The Responsibility to Protect in the Unipolar Era, Security Dialog, 2004, vol.35, no 2; N. MacFarlane, C. J. Thielking, T. G. Weiss, The Responsibility to Protect: is anyone interested in humanitarian intervention?, Third World Quarterly, 2004, vol. 25, no. 5; Sung-han Kim, The End of Humanitarian Intervention?, Orbis A Journal of World Affairs, 2003.

10 More about it - vid. International Commissions and The Power Of Ideas, eds. R. Thakur, A. F. Cooper, J. English, United Nations University Press, New York 2005, p. X.

11 Jerzy Zajadło wrote that "Something that just yesterday seemed to be a chimera of intellectuals, today is an official doctrine of the United Nations, and tomorrow may become a binding legal norm" in: J. Zajadło, Konstytucjonalizacja prawa międzynarodowego, Państwo i Prawo, 2011, 
100 | Adam Mickiewicz University Law Review

\section{Internal R2P Dynamics}

Further development of the concept was only a matter of time - the idea started to live a life of its own. Numerous international documents and rich literature referred to states' responsibility for the protection of their citizens and the international community's responsibility for its reactions to the violations of citizens' rights. However, R2P dynamics meant not only acceleration in time, but also changes in the concept structure. In the initial version proposed by the ICISS report, responsibility to protect rested primarily with the state. Only if the state is unwilling or unable to perform its duties, or is the author of violations itself, is the responsibility to protect shifted to the international community. Eventually the responsibility to protect means not only the responsibility to undertake action, but also to prevent and rebuild. Extended work conducted within the UN system and numerous discussions held at the General Assembly meetings revealed the states' doubts concerning individual elements of the concept. In 2009 the Secretary-General presented the Implementing the Responsibility to Protect report, which included a thorough interpretation of Summit Outcome Document paragraphs and created a new vision of the responsibility to protect concept. The modified R2P version took into account a theory added to three responsibility pillars adopted by ICISS: to prevent, to react, and to rebuild ${ }^{12}$. The first pillar outlines that it is primarily the state that is responsible for protecting its populations from genocide, war crimes, ethnic cleansing and crimes against humanity. The second pillar asserts that the international community should help states to protect their populations. And finally, it is the international community that is responsible for a timely and decisive response aimed at crime prevention if a state is manifestly failing to protect its population.

\section{External R2P Institutionalization}

The fact of active institutionalization of the R2P concept and the development of infrastructure around it is also unparalleled. Two new offices for R2P effective development and implementation were established: the Special Adviser of the Secretary-General on the Prevention of Genocide ${ }^{13}$ and the Special Adviser of the Secretary-General on the Responsibility to Protect ${ }^{14}$. Moreover, numerous international structures have been established that cooperate on the popularization of the R2P concept. Civil society organ-

vol. 3, p. 17; R. J. Hamilton, The Responsibility to Protect: From Document to doctrine - but what of implementation?, Harvard Human Rights Law Journal, 2006, vol. 19, pp. 289-297.

12 More about it - vid. A. J. Bellamy, Global Politics and the Responsibility to Protect: From Words to Deeds, Routledge, London-New York 2011, pp. 35 et seq.

13 Initially held by Francis M. Deng; then, from July 2012, by Adam Dieng.

14 Initially held by Edward C. Luck; then, from 2012, by Jennifer Welsh; now, from 2016, by Ivan Šimonović. 
isations, such as the Global Centre for the Responsibility to Protect and the International Coalition for the Responsibility to Protect, as well as non-governmental regional organisations, such as the Asia-Pacific Centre for the Responsibility to Protect, have been established to actively support R2P development. The concept is also popularized on a virtual basis - in the form of the www.responsibilitytoprotect.org website and the Global Responsibility to Protect Journal published since 2009. Numerous direct and indirect references to R2P in the UN documents cited above, Security Council resolutions in particular, are undoubtedly expressions of the concept's institutionalization on a normative level.

\section{Risks and Deficiencies}

Opinions about the Responsibility to Protect concept take both the form of praise and criticism. Even if we acknowledge all the above-mentioned positive aspects and advantages of R2P, it is hard to ignore the risks that may result from the erroneous interpretation of the concept or its overuse for instrumental purposes, as well as its deficiencies connected with the still unresolved problem of the gap between the legality and legitimacy of the use of force in international relations. The new world order offers an equal number of benefits and risks. The theory - initially only intellectually challenging - started to gain normative characteristics. It must be remembered, however, that it is still an idea that requires a great deal of work before it is effectively realized. Thus, many postulates de lege ferenda are still formulated. The risk that the concept might be used for inappropriate purposes is still high. In the past there were several attempts to use R2P in situations that did not fulfil the prerequisites of legitimacy. In 2008 the government of Russia invoked the responsibility to protect concept in the context of its military intervention in Georgia - the Russian authorities claimed that there was a direct risk of crime against the populations of South Ossetia and that they initiated action solely out of humanitarian motives. The analysis of the Russo-Georgian War shows that an intervention under R2P pretext should fulfil three main prerequisites. Firstly, Russia's claim that it protected its own citizens in another country did not fulfil the responsibility to protect criterion and could only be used as the grounds for self-defence. Secondly, the scale and the range of Russian actions undertaken there far exceeded the limits of direct protection of peoples against human rights violations. And thirdly, the lack of unanimous consent of the United Nations Security Council's permanent members means there is a lack of legal authorisation to use force under the framework of the Responsibility to Protect. Thus, in this case no criteria were fulfilled that could justify the use of the R2P concept. References to R2P were also made in the context of a humanitarian disaster, after the destruction caused in Myanmar in May 2008 by Cyclone Nargis. Opinions differ 
in this case. On the one hand, Bernard Kouchner, the ex-Minister of Foreign Affairs of France, invoked R2P and justified its application due to the occurrence on a mass scale of suffering, hunger and death. It must be remembered, however, that the responsibility to protect has been limited to four crimes and this catalogue should not be extended. Ramesh Thakur acknowledged that it is inadequate to refer to R2P in the context of the Myanmar crisis: "I can think of no better way to damage R2P beyond repair in Asia and most of the rest of the developing world than have the humanitarian assistance delivered into Burma backed by Western soldiers fighting in the jungles of Southeast Asia again"15. The risk occurs also in the situation when the concept has initially fulfilled criteria of legality, but as a result of its application has lost the legitimacy of the international community - as happened in the case of Libya. Thus, there is both a risk the concept will be used for inadequate purposes, like in case of Georgia and Myanmar, and a risk that concept expansion will be used during interventions that have already been undertaken, as in case of Libya where the concept evolved from the need to protect civil population to the intention to change the regime and call Muammar Gaddafi to account. At the same time we must notice the positive influence of R2P on the United Nations Security Council - the Council suggested that its members not use their veto rights in situations that do not endanger their interests. However, the problem of the authorization of military action by the Security Council is still unresolved and returns every now and again. Thus, it is hard to envision the future of the Responsibility to Protect concept.

Observation of current events in the world (in Libya, Syria, and Ukraine, among others) leads to the sad conclusion that the risk of constant arguments and never-ending conflicts of various aetiology is inevitable. That is why Gareth Evans is of the opinion that the perspective of the ineffectiveness of international community's reactions may cause frustration, disappointment and disgust ${ }^{16}$. Although he optimistically notices at the same time that the R2P principle is universally supported and the only thing that is missing is its actual application in the most difficult situations. Nevertheless, the responsibility to protect concept - so innovative and controversial in its premises - rather than lose its value, gains in importance in the eyes of the international community and gradually leads to a legal theory being formed ${ }^{17}$. We still can hope that current international law will gradually support and incorporate the R2P concept and the international

15 Cited from: Cyclone Nargis and the Responsibility to Protect Myanmar/Burma Briefing no. 2 of 16 May 2008, Asia-Pacific Center for the Responsibility to Protect, available at http://www. responsibilitytoprotect.org/legacyDownload.php? module=uploads \&func=download $\&$ file $\mathrm{Id}=539$.

16 G. Evans, The evolution of the Responsibility to Protect: from concept and principle to actionable norm, in: Theorising the Responsibility to Protect, eds. R. Thakur, W. Maley, Cambridge University Press, Cambridge 2015, p. 37.

17 M. Hakimi, Toward a Legal Theory on the Responsibility to Protect, The Yale Journal of International Law 2014, vol. 39, no. 2, pp. 247-281. 
community will show a greater enthusiasm for establishing a legal framework for the concept and determining the correct guidelines for its application.

\section{The Up-to-Dateness of the Debate in the Literature}

Numerous publications concerning R2P are the best illustration of the fact that it is a very topical subject. The analysis of all doctrinal issues focusing on new challenges for contemporary international law would go far beyond the scope of this article; that is why it is advisable to limit our considerations to key trends in the international discourse on R2P.

Firstly, we observe a visible change in the international law paradigm. It can be seen in the symptomatic titles of selected works: The Responsibility to Protect (R2P): A new Paradigm of International Law? ${ }^{18}$, The Responsibility to Protect in International Law. An emerging paradigm shift ${ }^{19}$, or Theorising the Responsibility to Protect ${ }^{20}$ edited by Ramesh Thakur (one of the "fathers" of R2P concept) and William Maley.

Secondly, more and more often we hear that a moral norm transforms into a legal one $^{21}$. Although the conclusions of the 2005 World Summit (paragraphs 138 and 139 of the Outcome Document) are perceived as soft law at its best ${ }^{22}$ or an opinio iuris expression of the collective action of states in the spirit of the newly formed R2P norm ${ }^{23}$, it is hard to deny that at present the implementation of the norm has got the features of a legal norm. When reviewing the development of the R2P concept, its implementation and the institutional engagement of the international community, Gareth Evans clearly sees the concept evolving towards an operating norm ${ }^{24}$ and Luke Glenville demonstrates that R2P clearly affects the actions of states, particularly in situations when military intervention is taken into account ${ }^{25}$.

18 P. Hilpold, The Responsibility to Protect (R2P): A new Paradigm of International Law?, Brill, Leiden-Boston 2014.

19 S. Breau, The Responsibility to Protect in International Law An emerging paradigm shift, Routledge, London-New York 2016.

20 Theorising the Responsibility to Protect, eds. R. Thakur, W. Maley, Cambridge University Press, Cambridge 2015.

21 P. G. Ercan, Debating the Future of the 'Responsibility to Protect': The Evolution of a Moral Norm, Palgrave Macmillan, London 2016.

22 J. Welsh, Norm Contestation and the Responsibility to Protect, Global Responsibility to Protect, vol. 5 , no. 4, p. 376.

23 A. Bloomfield, Resisting the Responsibility to Protect, in: Norm Antipreneurs and the Politics of Resistance to Global Normative Change, eds. A. Bloomfield, S. V. Scott, Routledge, LondonNew York 2017, pp. 20-39.

24 G. Evans, op. cit., p. 16-37.

25 L. Glenville, Does R2P matter? Interpreting the impact of a norm, Cooperation and Conflict, Vol. 51, no. 2, pp.184-199. 
Thirdly, the international community makes increasingly effective use of the instruments it has got at hand to apply the third pillar of $\mathrm{R}_{2} \mathrm{P}^{26}$ (i.e. responsibility to react): economic sanctions, arms embargoes, targeted diplomatic sanctions, effective international criminal law jurisdiction, cooperation with regional and sub-regional organisations, and, as a last resort, force measures authorized by the Security Council. Tragic events occurring nowadays (e.g. in Libya, Syria, the Central African Republic - to mention just a few of them) show an urgent need to conduct discussion on the effectiveness of creating and using practical instruments for the application of the R2P third pillar. The authors of The Responsibility to Protect and the Third Pillar ${ }^{27}$ collective publication attempt to analyze the operationalization of the responsibility to protect norms within the third pillar: its legitimacy, proportionality, and effectiveness of undertaken actions: "Pillar three of the Responsibility to Protect (RtoP) focuses on the international community's responsibility to take 'timely and decisive action' to prevent and halt genocide, ethnic cleansing, war crimes and crimes against humanity in those instances where a state is unable or unwilling to protect its own populations. A range of tools have been devised to aid in this 'timely and decisive action': economic sanctions, international criminal trials and, most controversially, the use of force. The recent crises that have erupted in places such as Libya, Syria and the Central African Republic highlight the continued relevance of the RtoP debate, but it also gives rise to the need to better understand the processes, opportunities and risks involved in moving from the RtoP as a norm to its operationalization under the third pillar. Important questions related to the timeliness, legitimacy, proportionality and effectiveness of pillarthree responses need fleshing out and critically analyzing. Furthermore, there is further scope in apprehending how third pillar activities interact with, and mutually affect, the first and second pillars, and preventive and re-building initiatives aimed at avoiding pillar-three situations from occurring in the first place”.

And finally, the application of $\mathrm{R} 2 \mathrm{P}$ concept on the regional level stirs a growing interest the African continent and the African Union as a regional organisation are the best examples here. In the literature this tendency can be seen in the publication entitled Humanitarian Intervention and the AU-ECOWAS Intervention Treaties Under International Law ${ }^{28}$. It seems to be an understandable trend, because at such a level it is sometimes easier to achieve ef-

26 Implementing the Responsibility to Protect, the third pillar of the R2P concept defined in the Report of the Secretary-General of 20 January 2009 concentrates on the responsibility of the international community for timely and decisive response aiming at the prevention and stopping of genocide, ethnic cleansing, war crimes, and crimes against humanity if a state is manifestly failing to protect its population.

27 The Responsibility to Protect and the Third Pillar. Legitimacy and Operationalization, eds. D. Fiott, J. Koops, Palgrave Macmillan, 2015, p.1.

$28 \mathrm{~J}$. M. Iyi, Humanitarian Intervention and the AU-ECOWAS Intervention Treaties Under International Law. Towards a Theory of Regional Responsibility to Protect, Springer International Publishing, 2016 
fective operationalization among states connected by the same culture, tradition or level of economic or political development: "Thus, by the dawn of the twenty-first century, just as the ICISS was working to reconceptualise sovereignty, ECOWAS and the African Union (successor to the OAU) were revising the legal framework of collective security in their respective constitutive documents. But the old debates largely remained. The tension between sovereignty and human rights protection, the legality of unauthorised use of force by regional organisations and the legitimacy of the contemporary international legal order in the face of the failure to protect people from genocide and other mass atrocity crimes dominated the debates. In most of these debates, Africa's conflict zones often provided the analytic framework for evaluating the effectiveness of the UN in responding to mass atrocities and the role of international law in the process. The broad consensus in the assessments by the different commissions and studies mentioned above was that the existing system was not effectively responding to the protection of populations from gross violations of human rights within states and that there was an urgent need for reform. The new approach to collective security by ECOWAS and the AU were feeding into this lacuna. However, the legal basis of this AU and ECOWAS approach calls for examination as it raises several legal issues with respect to the UN Charter law on the use of force although the approach may well become the paradigm for future action on the Responsibility to Protect (R2P)"29.

\section{Literature}

Bellamy A. J., Global Politics and the Responsibility to Protect: From Words to Deeds, Routledge, London-New York 2011.

Bloomfield A., Resisting the Responsibility to Protect, Norm Antipreneurs and the Politics of Resistance to Global Normative Change, eds. A. Bloomfield, S. V. Scott, Routledge, London--New York 2017.

Breau S., The Responsibility to Protect in International Law An emerging paradigm shift, Routledge, London-New York 2016.

de la Rasilla del Moral I., The Unsolved Riddle of International Constitutionalism, "International Community Law Review”, 2010, vol.12, no 1.

Domingo R., The New Global Law, Cambridge University Press, New York 2011.

Ercan G., Debating the Future of the 'Responsibility to Protect': The Evolution of a Moral Norm, Palgrave Macmillan, London 2016.

Evans G., The evolution of the Responsibility to Protect: from concept and principle to actionable norm, Theorising the Responsibility to Protect, eds. R. Thakur, W. Maley, Theorising the Responsibility to Protect, Cambridge University Press, Cambridge 2015.

29 Ibidem, p. 4. 
106 | Adam Mickiewicz University Law Review

Hakimi M., Toward a Legal Theory on the Responsibility to Protect, The Yale Journal of International Law 2014, vol. 39, no. 2.

Hamilton R. J., The Responsibility to Protect: From Document to doctrine - but what of implementation?, "Harvard Human Rights Law Journal", 2006, vol. 19.

Hilpold P., The Responsibility to Protect (R2P): A new Paradigm of International Law?, Brill, Leiden--Boston 2014.

Zajadło J., Konstytucjonalizacja prawa międzynarodowego, Leksykon prawa międzynarodowego publicznego. 100 podstawowych pojęć, eds. A. Przyborowska Klimczak, D. Pyć, C. H. Beck, Warszawa 2012.

Iyi J. M., Humanitarian Intervention and the AU-ECOWAS Intervention Treaties Under International Law. Towards a Theory of Regional Responsibility to Protect, Springer International Publishing, 2016.

Glenville L., Does R2P matter? Interpreting the impact of a norm, "Cooperation and Conflict", vol. 51, no. 2.

MacFarlane N., Thielking C. J., Weiss T. G., The Responsibility to Protect: is anyone interested in humanitarian intervention?, "Third World Quarterly" 2004, vol. 25, no. 5.

Peters A., Humanity as $A$ and $\Omega$ [Omega] of Sovereignty, "European Journal of International Law" 2009, vol. 20, no 3.

Sung-han Kim, The End of Humanitarian Intervention?, Orbis A Journal of World Affairs, 2003.

Teitel R. G., Humanity's Law, Oxford University Press, Oxford-New York 2011.

The Responsibility to Protect and the Third Pillar. Legitimacy and Operationalizatio, eds. D. D. Fiott, J. Koops, Palgrave Macmillan, 2015.

Theorising the Responsibility to Protect, eds. R. Thakur, W. Maley, Cambridge University Press, Cambridge 2015.

Trynidade A. A. C., International Law for Humankind, Brill, Boston-Leiden 2010.

Weiss T. G., The Sunset of Humanitarian Intervention? The Responsibility to Protect in the Unipolar Era, Security Dialog, 2004, vol. 35, no. 2.

Welsh J., Norm Contestation and the Responsibility to Protect, Global Responsibility to Protect, vol. 5, no. 4.

Wiśniewski A.,Fragmentacjaprawa międzynarodowego, Leksykon prawa międzynarodowego publicznego. 100 podstawowych pojęć, eds. A. Przyborowska Klimczak, D. Pyć, C. H. Beck, Warszawa 2012.

Zajadło J., Konstytucjonalizacja prawa międzynarodowego, "Państwo i Prawo", 2011, vol. 3. Zajadło J., Aksjologia Prawa Międzynarodowego a fllozofia prawa (uwagi na marginesie doktryny Responsibility to Protect), Aksjologia wspótczesnego prawa międzynarodowego, ed. A. Wnukiewicz-Kozłowska, Wydawnictwo Uniwersytetu Wrocławskiego, Wrocław 2011. 


\section{SUMMARY}

\section{The Up-to-Dateness of the Debate on Responsibility to Protect}

The aim of the article is to review the contemporary debate on the concept of Responsibility to Protect. Numerous publications concerning R2P are the best illustration of the fact that it is a very topical subject. Analysing the doctrinal issues focusing on new challenges for contemporary international law the author focuse on a visible change in the international law paradigm, transformation of moral norm into legal one and the effective use of the instruments of $\mathrm{R} 2 \mathrm{P}$ application.

Keywords: Responsibility to Protect, public international law

Paulina ZajadŁo-Węglarz, University of Gdańsk, Faculty of Law and Administration, Al. Niepodległości 53, 61-714 Poznań, e-mail: paulina.zajadlo@prawo.ug.edu.pl. 
